\title{
Coxiella burnetii seroprevalence and risk factors in sheep farmers and farm residents in The Netherlands
}

\author{
M. M. A. De LANGE ${ }^{1 * \dagger}$, B. SCHIMMER ${ }^{1} \dagger$, P. VELlEMA ${ }^{2}$, J. L. A. HAUTVAST ${ }^{3}$, \\ P. M. SCHNEEBERGER ${ }^{4}$ AND Y. T. H. P. VAN DUIJNHOVEN ${ }^{1}$ \\ ${ }^{1}$ Centre for Infectious Disease Control Netherlands, National Institute for Public Health and the Environment \\ (RIVM), Bilthoven, The Netherlands \\ ${ }^{2}$ Department of Small Ruminant Health, Animal Health Service (GD), Deventer, The Netherlands \\ ${ }^{3}$ Department of Primary and Community Care, Academic Collaborative Centre for Public Health (AMPHI), \\ Radboud University Nijmegen Medical Centre, Nijmegen, The Netherlands \\ ${ }^{4}$ Department of Medical Microbiology and Infection Control, Jeroen Bosch Hospital,'s-Hertogenbosch, \\ The Netherlands
}

Received 15 January 2013; Final revision 17 May 2013; Accepted 3 July 2013;

first published online 7 August 2013

\section{SUMMARY}

In this study, Coxiella burnetii seroprevalence was assessed for dairy and non-dairy sheep farm residents in The Netherlands for 2009-2010. Risk factors for seropositivity were identified for non-dairy sheep farm residents. Participants completed farm-based and individual questionnaires. In addition, participants were tested for IgG and IgM C. burnetii antibodies using immunofluorescent assay. Risk factors were identified by univariate, multivariate logistic regression, and multivariate multilevel analyses. In dairy and non-dairy sheep farm residents, seroprevalence was $66 \cdot 7 \%$ and $51 \cdot 3 \%$, respectively. Significant risk factors were cattle contact, high goat density near the farm, sheep supplied from two provinces, high frequency of refreshing stable bedding, farm started before 1990 and presence of the Blessumer breed. Most risk factors indicate current or past goat and cattle exposure, with limited factors involving sheep. Subtyping human, cattle, goat, and sheep C. burnetii strains might elucidate their role in the infection risk of sheep farm residents.

Key words: Coxiellae, Q fever, risk assessment, serology, zoonoses.

\section{INTRODUCTION}

Q fever, caused by Coxiella burnetii, is a worldwide zoonosis with goats, sheep, and cattle as primary sources for human infections [1]. Humans are usually infected by inhalation of contaminated aerosols originating from parturient animals and their birth

\footnotetext{
* Author for correspondence: Mrs M. M. A. de Lange, Centre for Infectious Disease Control Netherlands, National Institute for Public Health and the Environment (RIVM), P.O. Box 1, 3720 BA, Bilthoven, The Netherlands. (Email: marit.de.lange@rivm.nl)

$\dagger$ These authors contributed equally to this work.
}

products [1-3]. Acute $Q$ fever presents itself as a selflimiting febrile illness, pneumonia or hepatitis, with a small proportion developing chronic infections (mainly endocarditis and vascular infections) $[4,5]$.

From 2007 until 2009, large Q fever outbreaks occurred in The Netherlands, with over 3500 human cases notified [6]. Abortion waves at dairy goat farms were the primary source of these infections [7-9]. Between 2006 and 2008, C. burnetii abortion waves occurred on two dairy sheep farms [9]. Infected non-dairy sheep farms were not associated with an increased number of human cases living near these farms [10], although cases occurred in

The online version of this article is published within an Open Access environment subject to the conditions of the Creative Commons

Attribution-NonCommercial-ShareAlike licence $<$ http://creativecommons.org/licenses/by-nc-sa/3.0/>. The written permission of

Cambridge University Press must be obtained for commercial re-use. 
individuals living a small distance from or having direct contact with non-dairy sheep in The Netherlands [11, 12]. Internationally, several sheeprelated Q fever outbreaks have been reported [13-19].

In The Netherlands, sheep farms can be distinguished from dairy farms and fat lamb-producing farms. There is a small dairy sheep industry with $<50$ farms, in which sheep are usually milked twice a day during several months each year. The number of sheep per farm differs from $<50$ to almost 1000 with most kept outdoors for part of the year. On the fat lamb-producing sheep farms the sheep are kept outside, except for a few weeks around lambing, which usually occurs inside. Except for meat production, non-dairy sheep are also kept for breeding purposes or nature management.

So far, no international studies have addressed the seroprevalence and risk factors for acquisition of C. burnetii infection in sheep farmers and their household members. Therefore, our aim was to determine the $C$. burnetii seroprevalence in both dairy and nondairy sheep farmers and their household members, and for the large non-dairy sector, to identify individual and farm-related risk factors for seropositivity.

\section{MATERIAL AND METHODS}

All dairy sheep and non-dairy sheep farms in The Netherlands with at least 100 breeding ewes in November 2008, according to the national identification and registration database, were eligible. A minimum of 100 ewes, considered to be a professional farm, was chosen because in the early stage of the Dutch epidemic it was clear that only (relatively large) commercial (dairy goat) farms were incriminated as a potential source; no obvious role for small farms was observed [9]. Besides, smaller hobby farms have different management and farm residents of those farms are assumed to have a more limited exposure to sheep-related pathogens compared to commercial farms. Between September and December 2009, 32 dairy sheep farmers were approached for the study. In addition, in March and April 2010, 1344 non-dairy sheep farmers were approached for participation. At the time of inclusion in 2010, those farms with at least 60 unvaccinated breeding animals were kept in the study. Farms with vaccinated sheep were excluded because in this integrated human-veterinary study the sheep at these farms were likely to be seropositive due to vaccination; vaccine-induced and naturally induced seroresponses cannot be distinguished to assess the true seroprevalence from natural infection. Second, we assumed that the infection rate for farm residents could be different for farms with vaccinated sheep (leading to reduced exposure) compared to farms with unvaccinated sheep. About 3 weeks after the initial invitation, all non-responding farmers were sent a written reminder. Because of the small number, dairy sheep farmers who did not respond to this second invitation were contacted by telephone.

After written informed consent, a maximum of three persons were selected from each farm, i.e. the farmer and a maximum of two family members aged $\geqslant 12$ years residing at the farm; in some instances other persons working or living on the farm were selected. Each participant received a questionnaire addressing individual-based risk factors like age, gender, profession, ownership or contact with ruminants and pets, consumption of unpasteurized milk, medical history, and contact with agricultural products. In addition, the farm owner or farm manager completed a farm-based questionnaire addressing characteristics like farm hygiene and management, herd size, presence of other livestock and pets, stable environment, and lambing season characteristics. Separate farm-based questionnaires were developed for dairy farms and non-dairy farms because of clear differences in farm management. A professional laboratory assistant visited the farms to collect blood samples from all participating individuals for serology. All data of the dairy sheep farms were collected between September 2009 and September 2010, for the non-dairy sheep farms data were collected between April and September 2010. The Medical Ethical Commission of the University Medical Center Utrecht approved the study protocol (no. 09-189/K).

\section{Serological analysis}

Serum samples were tested for $C$. burnetii $\operatorname{IgM}$ and IgG antibodies, both phases I and II, using an indirect immunofluorescence assay (IFA) with a screening dilution of 1:32. Participants without any positive antibody result and participants with a solitary IgM phase I or solitary IgM phase II result were classified as seronegative. All other outcomes were classified as seropositive. Those with IgM phase II antibodies were designated as 'relatively recent infections' and included possible current infections. The term 'relatively recent' was chosen as IgM phase II is found 
to persist in the majority of cases for 1 year post-infection and may even persist up to 4 years post-infection [20, 21] (C. C. H. Wielders, personal communication). Seropositives without IgM phase II antibodies were designated as 'past infections'. As the latter group also includes possible chronic infections, a further distinction was made between serological profiles that had IgG phase $I \geqslant 1: 1024$ indicative for a chronic infection according to the new Dutch consensus guidelines [22].

\section{Statistical analyses}

\section{Dairy sheep farms}

All data were analysed with SAS, version 9.2 (SAS Institute Inc., USA). For the dairy sheep farms in The Netherlands, participation bias was investigated by comparing participating and non-participating farms with regard to herd size, urbanization degree and region. The seroprevalence of $C$. burnetii in residents and the corresponding $95 \%$ confidence interval (CI) were calculated. Descriptive statistics were performed by analysing frequency tables and studying distributions of continuous variables. No risk factor analysis was performed because of the small number of participants.

\section{Non-dairy sheep farms}

To study participation bias, participating and nonparticipating farms were compared with regard to herd size, cattle, sheep, and goat density in the surroundings, urbanization degree, region, situated inside or outside a compulsory $\mathrm{Q}$ fever vaccination area, number of bulk-milk-positive dairy goat or dairy sheep farms in a radius of 5 and $10 \mathrm{~km}$, and distance in metres to the closest bulk-milk-positive small ruminant farm.

The seroprevalence of $C$. burnetii and the corresponding 95\% CI were calculated. For descriptive statistics, frequency tables were analysed. In addition, distributions of continuous variables were studied, and if not linearly related to the outcome variable, continuous variables were recoded into classes.

Univariate logistic regression analysis was performed to assess the main factors associated with $C$. burnetii seropositivity at the individual level $[P<0 \cdot 20$ in the likelihood ratio test $(-2 \mathrm{LL})]$. Variables with $<20$ participants in one risk category were excluded. Age was always kept in the model because of the frequent association with $\mathrm{Q}$ fever seropositivity in the literature. Proxy outcomes, such as sheep seropositivity, were not included in the multivariate analysis. If several variables, which were associated in the univariate analysis, were interrelated, a preferred variable was chosen and related variables were excluded. The preferred variable was chosen based on the most informative value, the strongest association or most relevant exposure (exposure at own farm instead of comparable exposure at other farms). All identified individual variables were analysed with a manual backwards elimination procedure until all variables were significant at the $10 \%$ significance level in the likelihood ratio test, starting with a full multivariate logistic regression model.

Subsequently, potential risk factors derived from the farm-based questionnaire were analysed by univariate multilevel analyses considering clustered farmbased data for all persons within the same farm, using a unique farm number as cluster variable. All farm variables which were significant in the univariate analysis $(P<0 \cdot 20)$, were analysed with a manual backward elimination procedure starting with a full multilevel model.

Finally, both the individual and farm-based characteristics from the two final submodels were combined in a multivariate multilevel analysis to identify the independent risk determinants for C. burnetii seropositivity. The final model fit was assessed by the quasi-likelihood under the independence model criterion (QIC) goodness-of-fit statistic for generalized estimation equation (GEE) models.

\section{RESULTS}

\section{Dairy sheep farms}

Out of the 32 invited farms, 12 participated (response rate $37 \cdot 5 \%$ ). The participating farms were all situated in a rural area $\left(<500\right.$ addresses $\left./ \mathrm{km}^{2}\right)$. Participating and non-participating farms were comparable with regard to urbanization degree and province distribution. However, participating farms had a median number of 529 sheep (range 143-1163) vs. the significantly lower median of 353 sheep (range 96-730) for non-participating farms $(P=0 \cdot 03)$.

Twenty-seven study participants (mean age 38.7 years, range $14-61,63 \%$ male), provided a blood sample. Overall, $18(66 \cdot 7 \%)$ participants were seropositive: $80 \cdot 0 \%$ for the 15 farmers (12 males), and $50.0 \%$ for the 12 household members (five children, five female spouses, one male spouse, one 
seasonal worker). Three (11.1\%) participants had a relatively recent $C$. burnetii infection (IgM phase II antibodies). None consulted their general practitioner or were hospitalized because of influenza-like illness or fever. One participant had an IgG phase I titre of $\geqslant 1: 1024$, indicating a possible chronic case [22].

\section{Non-dairy sheep farms}

Non-response analyses

Out of the 1344 approached farms, at least 32 appeared to be no longer eligible because they had $<60$ animals at inclusion or had vaccinated all their sheep. Of the remaining 1312 farms, 119 participated in the study (response rate $9 \cdot 1 \%$ ).

A significant difference was found for sheep density in the $5-\mathrm{km}$ radius of participating and nonparticipating farms, 34.5 (range $1 \cdot 8-143.6$ ) and 47.5 (range $1 \cdot 0-162 \cdot 9$ ) sheep $/ \mathrm{km}^{2}$ in the $5-\mathrm{km}$ radius (excluding own sheep), respectively $(P=0 \cdot 01)$. In addition, the number of sheep was borderline significantly higher at the participating farms (median 191 sheep, range 102-1310), compared to the nonparticipating farms (median 167 sheep, range 100-2857). For the other variables, no significant differences were found between participating and nonparticipating farms (Table 1).

\section{Descriptive characteristics}

The 119 participating farms were mainly situated in the provinces of Noord-Holland and Friesland, commonly $(90 \cdot 8 \%)$ situated in rural areas $(<500$ addresses $/ \mathrm{km}^{2}$ ) and the most common breeds at the farms were Texel (57.0\%) and Swifter (46.5\%). The farms were mainly started after $1950(9 \cdot 6 \%$ $1875-1950,39 \cdot 4 \%$ 1951-1980, $51 \cdot 0 \%$ after 1980). Out of the 114 farms with a farm-based questionnaire, $23(20 \cdot 2 \%)$ kept one or more goats, $45(39 \cdot 5 \%)$ kept dairy cattle and/or beef cattle, and $13(11.4 \%)$ other farms reported that cattle were present on their pastures. The farms could have one or more function; $95(83.3 \%)$ farms kept sheep for meat production, $53(46.5 \%)$ farms for rearing, and $20(17 \cdot 5 \%)$ farms for nature management. Of those 20 farms, 12 farms kept their sheep exclusively for nature management.

From the 119 farms, 271 persons provided a blood sample (mean age 47, range $12-93$ years, 55\% male). Of those, 266 completed the individual selfadministered questionnaire and from 261 individuals information was available from the farm-based questionnaire.

C. burnetii seroprevalence was $51 \cdot 3 \%$ (95\% CI $45 \cdot 5-57 \cdot 4)$. In the univariate analysis, seroprevalence was significantly higher for farmers $(58 \cdot 8 \%$ vs. $36 \cdot 3 \%$ for spouses) and for males $(57.7 \%$ vs. $43.4 \%$ for females). Out of the 271 participants, seven $(2 \cdot 6 \%)$ had a relatively recent infection (IgM phase II antibodies). No participant had an IgG phase I titre suggestive for chronic infection.

Although the seroprevalence of the farm residents was higher for those living on a dairy sheep farm, the difference was not statistically significant [odds ratio (OR) $1 \cdot 9,95 \%$ CI $0 \cdot 8-4 \cdot 4]$ for dairy sheep farmers $v s$. non-dairy sheep farmers).

\section{Univariate analyses at individual and farm level}

All individual and farm-based variables, which were tested in the univariate analysis for relationship with human $C$. burnetii seropositivity, are displayed in Tables 2 and 3 .

\section{Multivariate and multilevel analyses}

In the multivariate analyses, from 23 individual variables which were associated in the univariate analysis, four were independently associated with $C$. burnetii seropositivity (Table 4). In addition, 10/23 farm-based variables included in the multilevel analyses were significantly independent risk or protective factors and together were used as the full multilevel start model (Table 5).

\section{Combined multilevel analyses of individual and farm-based factors}

In the final combined multilevel model, significant risk factors were contact with cattle at own or other farm, past employment in the cattle sector, high goat density in the vicinity of the farm, living or working at a farm that was started in 1990 or later, the presence of Blessumer breed on the farm, cattle on the same pastures used by sheep, although not simultaneously with the sheep, high frequency of refreshing the bedding in the sheep stables, and sheep supplied from the provinces of Groningen or Noord-Holland (Table 6). Borderline significant risk factors were age 40-49 years, and presence of dairy cattle during the stabling period of the sheep. In addition, sheep lambing outside was a significant protective factor, and air entering the stable through the door was a borderline significant protective factor. 
Table 1. Non-response analyses of non-dairy sheep farms, comparison of participating and non-participating farms

\begin{tabular}{|c|c|c|c|}
\hline Numerical variables & $\begin{array}{l}\text { Participating } \\
\text { farms }(N=119) \\
\text { Median }\end{array}$ & $\begin{array}{l}\text { Non-participating } \\
\text { farms }(N=1193) \\
\text { Median }\end{array}$ & $P$ value \\
\hline Number of sheep & 191 & 167 & $0 \cdot 05$ \\
\hline Cattle density (number of cattle $/ \mathrm{km}^{2}$ in the municipality)* & $134 \cdot 7$ & $135 \cdot 5$ & $0 \cdot 16$ \\
\hline $\begin{array}{l}\text { Cattle density without veal calves (number of cattle } / \mathrm{km}^{2} \\
\text { in the municipality)* }\end{array}$ & $114 \cdot 7$ & $119 \cdot 5$ & $0 \cdot 10$ \\
\hline $\begin{array}{l}\text { Goat density (number of goats } / \mathrm{km}^{2} \text { excluding own animals } \\
\text { in a } 5-\mathrm{km} \text { radius)* }\end{array}$ & $2 \cdot 6$ & $3 \cdot 5$ & $0 \cdot 17$ \\
\hline $\begin{array}{l}\text { Sheep density (number of sheep } / \mathrm{km}^{2} \text { excluding own animals } \\
\text { in a } 5-\mathrm{km} \text { radius)* }\end{array}$ & $34 \cdot 5$ & $47 \cdot 5$ & $0 \cdot 01$ \\
\hline $\begin{array}{l}\text { Closest Q fever bulk-milk-positive dairy goat or dairy } \\
\text { sheep farm (metres)* }\end{array}$ & 13960 & 13806 & $0 \cdot 70$ \\
\hline $\begin{array}{l}\text { Number Q fever bulk-milk-positive dairy goat or dairy } \\
\text { sheep farms in a 5-km radius* }\end{array}$ & $0(\min =0, \max =2)$ & $0(\min =0, \max =4)$ & $0 \cdot 62$ \\
\hline $\begin{array}{l}\text { Number } Q \text { fever bulk-milk-positive dairy goat or dairy } \\
\text { sheep farms in a 10-km radius* }\end{array}$ & $0(\min =0, \max =4)$ & $0(\min =0, \max =9)$ & $0 \cdot 71$ \\
\hline Categorical variables & $n(\%)$ & $n(\%)$ & $P$ value \\
\hline $\begin{array}{l}\text { Inside vaccination area } \\
\text { Outside vaccination area }\end{array}$ & $\begin{array}{l}20(16 \cdot 8) \\
99(83 \cdot 2)\end{array}$ & $\begin{array}{l}181(15 \cdot 2) \\
1012(84 \cdot 8)\end{array}$ & $0 \cdot 64$ \\
\hline $\begin{array}{l}\text { Urbanization } \\
\text { Very high urban area*† } \\
\text { High urban area } \\
\text { Moderate urban area } \\
\text { Minor urban area } \\
\text { Rural area }\end{array}$ & $\begin{array}{l}0(0 \cdot 0) \\
0(0 \cdot 0) \\
4(3 \cdot 3) \\
7(5 \cdot 9) \\
108(90 \cdot 8)\end{array}$ & $\begin{array}{l}2(0 \cdot 2) \\
3(0 \cdot 3) \\
14(1 \cdot 2) \\
84(7 \cdot 0) \\
1086(91 \cdot 3)\end{array}$ & $0 \cdot 37$ \\
\hline $\begin{array}{l}\text { Province } \\
\text { Drenthe* } \\
\text { Flevoland } \\
\text { Friesland } \\
\text { Gelderland } \\
\text { Groningen } \\
\text { Limburg } \\
\text { Noord-Brabant } \\
\text { Noord-Holland } \\
\text { Overijsel } \\
\text { Utrecht } \\
\text { Zeeland } \\
\text { Zuid-Holland }\end{array}$ & $\begin{array}{l}4(3 \cdot 4) \\
1(0 \cdot 8) \\
18(15 \cdot 1) \\
14(11 \cdot 8) \\
11(9 \cdot 2) \\
4(3 \cdot 4) \\
12(10 \cdot 1) \\
29(24 \cdot 4) \\
11(9 \cdot 2) \\
2(1 \cdot 7) \\
2(1 \cdot 7) \\
11(9 \cdot 2)\end{array}$ & $\begin{array}{l}57(4 \cdot 8) \\
9(0 \cdot 8) \\
213(17 \cdot 9) \\
170(14 \cdot 3) \\
93(7 \cdot 8) \\
23(1 \cdot 9) \\
74(6 \cdot 2) \\
241(20 \cdot 3) \\
86(7 \cdot 2) \\
48(4 \cdot 1) \\
49(4 \cdot 1) \\
126(10 \cdot 6)\end{array}$ & $0 \cdot 52$ \\
\hline
\end{tabular}

$N$, Total number of individuals.

* Four missing values at non-participating farms.

† Urbanization degree: very high urban area $>2500$ addresses $/ \mathrm{km}^{2}$; high urban area $=1500-2500$ addresses $/ \mathrm{km}^{2}$; moderate urban area $=1000-1500$ addresses $/ \mathrm{km}^{2} ;$ minor urban area $=500-1000$ addresses $/ \mathrm{km}^{2} ;$ rural area $<500$ addresses $/ \mathrm{km}^{2}$.

\section{DISCUSSION}

\section{Seroprevalence}

The seroprevalence of non-dairy $(51 \cdot 3 \%)$ and dairy sheep farm residents $(66.7 \%)$ is clearly higher compared to the seroprevalence estimate of $2 \cdot 4 \%$ in the general population before the outbreak occurred in The Netherlands in 2006-2007. It is even higher compared to the seroprevalence found in a small community in the epicentre of the $\mathrm{Q}$ fever outbreak in $2007(25 \cdot 1 \%)$, and in blood donors in the most Q fever-affected areas in $2009(12 \cdot 2 \%)$, indicating that sheep farm residents have an increased life-time risk of acquiring a $C$. burnetii infection compared to the general Dutch population [7, 23, 24].

The observed seroprevalence in Dutch sheep farm households is also high compared to a study of sheep farmers in Sweden (28.5\%) [25], and of 
Table 2. Univariate logistic model of individual factors related to C. burnetii seropositivity in non-dairy sheep farm residents $(P<0 \cdot 20,-2 L L)$

\begin{tabular}{|c|c|c|c|c|}
\hline Variable & Category & $\begin{array}{l}\text { Frequency } \\
(N) \\
(N=266)\end{array}$ & $\begin{array}{l}\text { Sero- } \\
\text { prevalence } \\
(\%)\end{array}$ & OR $(95 \% \mathrm{CI})$ \\
\hline \multirow[t]{2}{*}{ Gender* } & Male & 144 & $57 \cdot 6$ & $1 \cdot 77(1 \cdot 09-2 \cdot 88)$ \\
\hline & Female & 122 & $43 \cdot 4$ & Reference \\
\hline \multirow[t]{5}{*}{ Age (years)* } & $12-19$ & 21 & $57 \cdot 1$ & $2 \cdot 04(0 \cdot 72-5 \cdot 76)$ \\
\hline & $20-39$ & 45 & $51 \cdot 1$ & $1 \cdot 60(0 \cdot 70-3 \cdot 63)$ \\
\hline & $40-49$ & 68 & $58 \cdot 8$ & $2 \cdot 18(1 \cdot 03-4 \cdot 63)$ \\
\hline & $50-59$ & 84 & $50 \cdot 0$ & $1 \cdot 53(0 \cdot 74-3 \cdot 13)$ \\
\hline & $>60$ & 48 & $39 \cdot 6$ & Reference \\
\hline \multirow[t]{3}{*}{ Work and/or live on farm } & Work and live & 188 & $53 \cdot 7$ & $1 \cdot 61(0 \cdot 83-3 \cdot 15)$ \\
\hline & Work, but not live & 35 & $48 \cdot 6$ & $1 \cdot 31(0 \cdot 53-3 \cdot 22)$ \\
\hline & Not work, but live & 43 & $41 \cdot 9$ & Reference \\
\hline \multirow[t]{4}{*}{ Function } & Farmer & 136 & $58 \cdot 8$ & $2 \cdot 51(1 \cdot 42-4 \cdot 44)$ \\
\hline & Spouse & 80 & $36 \cdot 3$ & Reference \\
\hline & Child $†$ & 39 & $53 \cdot 9$ & $2 \cdot 05(0 \cdot 94-4 \cdot 46)$ \\
\hline & Other: & 11 & $54 \cdot 6$ & $2 \cdot 11(0 \cdot 59-7 \cdot 53)$ \\
\hline \multirow[t]{4}{*}{ How often in stable } & Every day & 185 & $55 \cdot 7$ & Reference \\
\hline & Every week & 56 & $41 \cdot 1$ & $0 \cdot 56(0 \cdot 30-1 \cdot 02)$ \\
\hline & Every month & 10 & $50 \cdot 0$ & $0 \cdot 80(0 \cdot 22-2 \cdot 84)$ \\
\hline & Less than once a month/never & 15 & $33 \cdot 3$ & $0 \cdot 40(0 \cdot 13-1 \cdot 21)$ \\
\hline \multirow[t]{3}{*}{ Amount of work at farm* } & Full working week & 61 & $63 \cdot 9$ & $2 \cdot 39(1 \cdot 25-4 \cdot 56)$ \\
\hline & Up to half a working week & 97 & $52 \cdot 9$ & $1 \cdot 49(0 \cdot 86-2 \cdot 59)$ \\
\hline & Never/occasionally & 108 & $42 \cdot 6$ & Reference \\
\hline \multirow[t]{2}{*}{ Feed sheep* } & Yes & 225 & $55 \cdot 6$ & $3 \cdot 41(1 \cdot 63-7 \cdot 14)$ \\
\hline & No & 41 & $26 \cdot 8$ & Reference \\
\hline \multirow[t]{2}{*}{ Load and unload sheep } & Yes & 194 & $56 \cdot 2$ & $2 \cdot 14(1 \cdot 23-3 \cdot 72)$ \\
\hline & No & 72 & $37 \cdot 5$ & Reference \\
\hline \multirow[t]{2}{*}{ General healthcare of sheep } & Yes & 201 & $55 \cdot 7$ & $2 \cdot 15(1 \cdot 21-3 \cdot 82)$ \\
\hline & No & 65 & $36 \cdot 9$ & Reference \\
\hline \multirow[t]{2}{*}{ Remove manure } & Yes & 180 & $57 \cdot 8$ & $2 \cdot 31(1 \cdot 36-3 \cdot 92)$ \\
\hline & No & 86 & $37 \cdot 2$ & Reference \\
\hline \multirow[t]{2}{*}{ Spread manure* } & Yes & 124 & $58 \cdot 9$ & $1 \cdot 80(1 \cdot 10-2 \cdot 92)$ \\
\hline & No & 142 & $44 \cdot 4$ & Reference \\
\hline \multirow[t]{2}{*}{ Clean stables } & Yes & 167 & $56 \cdot 3$ & $1 \cdot 75(1.06-2 \cdot 89)$ \\
\hline & No & 99 & $42 \cdot 4$ & Reference \\
\hline \multirow[t]{2}{*}{ Administrative work } & Yes & 193 & $54 \cdot 4$ & $1.62(0.94-2 \cdot 78)$ \\
\hline & No & 73 & $42 \cdot 5$ & Reference \\
\hline \multirow[t]{2}{*}{ Wear overalls or boots* } & Yes & 234 & $54 \cdot 3$ & $3 \cdot 03(1 \cdot 35-6 \cdot 84)$ \\
\hline & No & 32 & $28 \cdot 1$ & Reference \\
\hline \multirow{2}{*}{$\begin{array}{l}\text { Contact with cattle at own or } \\
\text { other farm*\& }\end{array}$} & Yes & 172 & $63 \cdot 4$ & $4 \cdot 29(2 \cdot 49-7 \cdot 40)$ \\
\hline & No & 94 & $28 \cdot 7$ & Reference \\
\hline \multirow{2}{*}{$\begin{array}{l}\text { Contact with horses at own or } \\
\text { other farm*§ }\end{array}$} & Yes & 145 & $59 \cdot 3$ & $2 \cdot 07(1 \cdot 27-3 \cdot 38)$ \\
\hline & No & 121 & $41 \cdot 3$ & Reference \\
\hline \multirow[t]{2}{*}{ Contact with pigs at own farm*§ } & Yes & 24 & $37 \cdot 5$ & $0 \cdot 54(0 \cdot 23-1 \cdot 29)$ \\
\hline & No & 242 & $52 \cdot 5$ & Reference \\
\hline \multirow{2}{*}{$\begin{array}{l}\text { Indirect contact with poultry } \\
\text { at own farm*\| }\end{array}$} & Yes & 93 & $57 \cdot 0$ & $1 \cdot 44(0 \cdot 87-2 \cdot 39)$ \\
\hline & No & 173 & $48 \cdot 0$ & Reference \\
\hline \multirow{2}{*}{$\begin{array}{l}\text { Indirect contact with rats } \\
\text { at own farm*\| }\end{array}$} & Yes & 45 & $64 \cdot 4$ & $1.93(0 \cdot 99-3 \cdot 76)$ \\
\hline & No & 221 & $48 \cdot 4$ & Reference \\
\hline \multirow[t]{2}{*}{ Contact with goats at other farm*§ } & Yes & 32 & $62 \cdot 5$ & $1 \cdot 70(0 \cdot 79-3 \cdot 63)$ \\
\hline & No & 234 & $49 \cdot 6$ & Reference \\
\hline Contact with sheep at other farm*§ & Yes & 102 & $60 \cdot 8$ & $1 \cdot 89(1 \cdot 14-3 \cdot 12)$ \\
\hline & No & 164 & $45 \cdot 1$ & Reference \\
\hline Contact with dogs at other farm*§ & Yes & 112 & $58 \cdot 9$ & $1 \cdot 72(1 \cdot 05-2 \cdot 82)$ \\
\hline & No & 154 & $45 \cdot 5$ & Reference \\
\hline
\end{tabular}


Table 2 (cont.)

\begin{tabular}{|c|c|c|c|c|}
\hline Variable & Category & $\begin{array}{l}\text { Frequency } \\
(N) \\
(N=266)\end{array}$ & $\begin{array}{l}\text { Sero- } \\
\text { prevalence } \\
(\%)\end{array}$ & OR $(95 \% \mathrm{CI})$ \\
\hline \multirow{2}{*}{$\begin{array}{l}\text { Indirect contact with poultry } \\
\text { at other farm\| }\end{array}$} & Yes & 38 & $63 \cdot 2$ & $1 \cdot 78(0 \cdot 87-3 \cdot 61)$ \\
\hline & No & 228 & $49 \cdot 1$ & Reference \\
\hline \multirow{2}{*}{$\begin{array}{l}\text { Indirect contact with cats } \\
\text { at other farm*\| }\end{array}$} & Yes & 81 & $59 \cdot 3$ & $1 \cdot 60(0 \cdot 95-2 \cdot 72)$ \\
\hline & No & 185 & $47 \cdot 6$ & Reference \\
\hline \multirow[t]{2}{*}{ Direct contact with wool* } & Yes & 113 & $60 \cdot 2$ & $1 \cdot 89(1 \cdot 15-3 \cdot 09)$ \\
\hline & No & 153 & $44 \cdot 4$ & Reference \\
\hline \multirow{2}{*}{$\begin{array}{l}\text { Direct contact with hay, straw } \\
\text { or animal feed* }\end{array}$} & Yes & 228 & $54 \cdot 8$ & $2 \cdot 98(1 \cdot 41-6 \cdot 29)$ \\
\hline & No & 38 & $29 \cdot 0$ & Reference \\
\hline \multirow[t]{2}{*}{ Direct contact with raw milk } & Yes & 72 & $62 \cdot 5$ & $1 \cdot 91(1 \cdot 10-3 \cdot 32)$ \\
\hline & No & 193 & $46 \cdot 6$ & Reference \\
\hline \multirow{2}{*}{ Drink raw milk from cattle* } & Yes & 45 & $66 \cdot 7$ & $2 \cdot 17(1 \cdot 11-4 \cdot 26)$ \\
\hline & No & 221 & $48 \cdot 0$ & Reference \\
\hline \multirow{2}{*}{ Direct contact with cattle manure } & Yes & 110 & $68 \cdot 2$ & $3 \cdot 30(1 \cdot 97-5 \cdot 52)$ \\
\hline & No & 155 & $39 \cdot 4$ & Reference \\
\hline \multirow{2}{*}{$\begin{array}{l}\text { Direct contact with live-born animals } \\
\text { during lambing period }\end{array}$} & Yes & 246 & $53 \cdot 3$ & $3 \cdot 42(1 \cdot 21-9 \cdot 69)$ \\
\hline & No & 20 & $25 \cdot 0$ & Reference \\
\hline \multirow{2}{*}{$\begin{array}{l}\text { Direct contact with dead-born } \\
\text { animals/placenta* }\end{array}$} & Yes & 210 & $54 \cdot 3$ & $1 \cdot 84(1 \cdot 01-3 \cdot 35)$ \\
\hline & No & 56 & $39 \cdot 3$ & Reference \\
\hline \multirow[t]{2}{*}{ Tick bite* } & Yes & 61 & $42 \cdot 6$ & $0.64(0 \cdot 36-1 \cdot 14)$ \\
\hline & No & 205 & $53 \cdot 7$ & Reference \\
\hline \multirow{4}{*}{$\begin{array}{l}\text { Did not work in animal } \\
\text { husbandry/agriculture in the past } \\
\text { Employment in cattle sector in the past* }\end{array}$} & Yes & 114 & $39 \cdot 5$ & $0 \cdot 44(0 \cdot 27-0 \cdot 72)$ \\
\hline & No & 152 & $59 \cdot 9$ & Reference \\
\hline & Yes & 107 & $64 \cdot 5$ & $2 \cdot 49(1.50-4 \cdot 14)$ \\
\hline & No & 159 & $42 \cdot 1$ & Reference \\
\hline \multirow{5}{*}{$\begin{array}{l}\text { Worked in animal transport/ transport } \\
\text { of agricultural products in the past* } \\
\text { As a child lived at: }\end{array}$} & Yes & 37 & $70 \cdot 3$ & $2 \cdot 56(1 \cdot 21-5 \cdot 42)$ \\
\hline & No & 229 & $48 \cdot 0$ & Reference \\
\hline & Cattle farm & 151 & $59 \cdot 6$ & $2 \cdot 04(1 \cdot 18-3 \cdot 53)$ \\
\hline & Other kind of farm & 34 & $35 \cdot 3$ & $0.75(0.33-1.73)$ \\
\hline & No farm & 81 & $42 \cdot 0$ & Reference \\
\hline \multirow{2}{*}{$\begin{array}{l}\text { As a child worked in animal care/with } \\
\text { manure/hay/in vegetation care* }\end{array}$} & Yes & 178 & $56 \cdot 2$ & $1 \cdot 85(1 \cdot 10-3 \cdot 11)$ \\
\hline & No & 88 & $40 \cdot 9$ & Reference \\
\hline
\end{tabular}

$N$, Total number of individuals; OR, odds ratio; CI, confidence interval, -2LL, likelihood ratio test.

* Variables included in subsequent multivariate individual analyses before manual backward elimination.

$\dagger$ Children aged $<18$ years $(n=17)$ and older children $(n=22)$ of the farmer.

† Employees, shepherds, other family members.

$\S$ See animals at $<5 \mathrm{~m}$ or touch animals.

$\|$ See animals at $<5 \mathrm{~m}$.

farmers from all types of farms: $17 \cdot 8 \%$ in Poland, and $27 \cdot 3 \%$ in the UK $[26,27]$. Generally, it is difficult to compare international seroprevalence studies, because most studies use different tests or cut-off values. The cut-off value of the test in our study $(\geqslant 1: 32)$ was chosen because it allowed comparison with other population surveys conducted in The Netherlands [23, 28].

Dairy sheep farm residents had a higher seroprevalence compared to non-dairy sheep farm residents. Although no statistically significant difference in seroprevalence was found between the residents of both farm types, this might be due to lack of power because of the small number of participants from dairy sheep farms. In this study it was impossible to assess which risk factors were responsible for the higher seroprevalence in dairy sheep farm residents, due to the low number of participating dairy sheep farm residents. In addition, because of the differences in farm management, the farm-based questionnaires of both farm types were not the same, therefore pooling the analysis with the other sheep farm residents to increase power was not an option. Specific research, targeting all current dairy sheep farms 
in The Netherlands ( $n \sim 40)$, might elucidate further risk factors next to the higher sheep seroprevalence, explaining the higher seroprevalence in dairy sheep farm residents. Nevertheless, it might well be that dairy farm residents were more exposed to Coxiella, as the seroprevalence in dairy sheep at these same farms was significantly higher compared to that of non-dairy sheep (data not shown). A higher vulnerability for infection of breeds selected for milk production rather than for disease resistance has previously been observed for dairy cattle, dairy sheep, and dairy goats [29, 30]. In addition, dairy sheep are more often housed in stables compared to nondairy sheep which spend most of the year outside. Indoor housing might facilitate the spread of $C$. burnetii in dairy sheep and to humans. Moreover, the higher seroprevalence in dairy farm residents might be explained by more intense contact with dairy sheep.

The seroprevalence of the dairy sheep farm residents $(66 \cdot 7 \%)$ was comparable to the seroprevalence of dairy goat farm residents $(68.7 \%)$ in The Netherlands [28]. Furthermore, the percentage of relatively recent infections (clinical status unknown as no questions addressed current $\mathrm{Q}$ fever compatible symptoms) in the dairy sheep farm residents $(11 \cdot 1 \%)$ is comparable to that of the dairy goat farm residents $(11 \cdot 2 \%)$ [28]. Additionally, the percentage of participants with an indication for a possible chronic infection is also similarly high for dairy sheep and dairy goat farm residents $(3 \cdot 7 \%$ and $4 \cdot 1 \%$, respectively) [28]. In contrast, the percentage of relatively recent infections and possible chronic infections are lower for non-dairy sheep farm residents $(2 \cdot 6 \%$ and $0 \%$, respectively). Therefore, currently $C$. burnetii infection seems to be a more serious and on-going health problem in dairy goat and dairy sheep farm residents compared to non-dairy sheep farm residents, although the numbers are relatively small.

Although numbers are too low to draw any conclusion and do not allow for valid statistical testing, the 10 (three from dairy and seven from non-dairy farms) relatively recent (IgM phase II positive) cases were generally younger (median 37 years $v s$. median 50 years for the seronegatives), were more often male $(80 \% v s .48 \%)$ and more often lived on a dairy sheep farm $(30 \%$ of the recently infected vs. $6 \%$ of the seronegatives). This may point to ongoing infections especially in male dairy sheep farm residents, in the relatively early days of their contact with sheep.

\section{Risk and protective factors for non-dairy sheep farm residents}

One of the protective factors for $C$. burnetii seropositivty was sheep lambing outside. Farm residents might be less exposed to contaminated aerosols in that situation, compared to lambing inside stables.

In addition, several risk factors for $C$. burnetii seropositivity were identified in this study. McCaughey et al. [31] suggested in his study in the general population (age 12-64 years) that most people acquired C. burnetii infection between ages 25 and 34 years and after that age seroprevalence remained stable. This age trend was not seen in our study; sheep farm residents had already a high seroprevalence at young age (12-19 years). This might be explained by exposure to infected animals at a young age. The highest seroprevalence found in humans (age 40-49 years), matches the most common age group of notified clinical Q fever cases in The Netherlands [9]. The increased risk at this age seems not to be explained by differences in specific work activities, frequency of cattle contact, or hours worked. Perhaps host factors play a role in the increased risk, or it generally reflects regular exposure to the bacterium and repeated development of antibodies (booster effect), not adequately measured by the questions in the questionnaire.

Animal movement is a known risk factor for the transfer of microorganisms and should be discouraged [32, 33]. Why specifically supply of sheep from the northern provinces of Noord-Holland and Groningen showed an independent increased risk for infection of the farm residents is not clear. The seroprevalence in sheep in these two provinces was not significantly different from prevalences in other provinces, both in the current study (B. Schimmer et al., unpublished data) and in a previous study in 2008 using convenience serum samples from sheep [30].

It is also unknown why the fact that a farm started before 1990 was a risk factor. No change in farm management is known around that year that could influence the risk of a $C$. burnetii infection.

Having the Blessumer sheep breed on the farm was the next significant risk factor. This breed is a crossing of the breeds of Texel (non-dairy sheep) and Flemish sheep (dairy sheep); therefore, the Blessummer breed might have a lower disease resistance $[29,30]$. Differences in infection rates between sheep breeds have not yet been studied to investigate whether Blessumer sheep are more often infected. 
Table 3. Univariate multilevel analysis of farm-based factors related to C. burnetii seropositivity in non-dairy sheep farm residents $(P<0 \cdot 20)$

\begin{tabular}{|c|c|c|c|c|}
\hline Variable & Category & $\begin{array}{l}\text { Frequency } \\
(N) \\
(N=261)^{*}\end{array}$ & $\begin{array}{l}\text { Sero- } \\
\text { prevalence } \\
(\%)\end{array}$ & OR $(95 \% \mathrm{CI})$ \\
\hline \multirow[t]{2}{*}{ Urbanization $\uparrow \$ s$} & $\begin{array}{l}\text { Moderate or minor } \\
\text { urban area }\end{array}$ & 28 & $67 \cdot 9$ & $2 \cdot 00(0 \cdot 80-5 \cdot 04)$ \\
\hline & Rural area & 242 & $49 \cdot 2$ & Reference \\
\hline \multirow{3}{*}{$\begin{array}{l}\text { Goat density (number of goats } / \mathrm{km}^{2} \text { excluding } \\
\text { own animals in a } 5 \text {-km radius) } \dagger \S\end{array}$} & $<2 \cdot 9$ & 135 & $38 \cdot 5$ & Reference \\
\hline & $2 \cdot 9-11 \cdot 3$ & 67 & $68 \cdot 7$ & $3 \cdot 59(1 \cdot 86-6 \cdot 91)$ \\
\hline & $\geqslant 11 \cdot 4$ & 68 & $58 \cdot 8$ & $2 \cdot 38(1 \cdot 18-4 \cdot 79)$ \\
\hline \multirow{3}{*}{$\begin{array}{l}\text { Sheep density (number of sheep } / \mathrm{km}^{2} \text { excluding } \\
\text { own animals in } 5 \text { - } \mathrm{km} \text { radius) } \dagger \S\end{array}$} & $<33 \cdot 7$ & 133 & $41 \cdot 4$ & Reference \\
\hline & $33 \cdot 7-79 \cdot 0$ & 69 & $53 \cdot 6$ & $1 \cdot 68(0 \cdot 87-3 \cdot 25)$ \\
\hline & $\geqslant 79 \cdot 1$ & 68 & $67 \cdot 7$ & $2 \cdot 98(1 \cdot 54-5 \cdot 78)$ \\
\hline \multirow{2}{*}{$\begin{array}{l}\text { Cattle density (number of cattle } / \mathrm{km}^{2} \text { in the } \\
\text { municipality) } \dagger \S\end{array}$} & $<200 \cdot 0$ & 240 & $47 \cdot 9$ & Reference \\
\hline & $\geqslant 200 \cdot 0$ & 30 & $76 \cdot 7$ & $3 \cdot 20(1 \cdot 37-7 \cdot 51)$ \\
\hline \multirow{2}{*}{$\begin{array}{l}\text { Number of Q fever bulk-milk-positive dairy } \\
\text { goat or dairy sheep farms in a } 10 \text {-km radius } \dagger \S\end{array}$} & 0 & 166 & $45 \cdot 8$ & Reference \\
\hline & $1-4$ & 104 & $59 \cdot 6$ & $1 \cdot 78(1 \cdot 02-3 \cdot 11)$ \\
\hline \multirow{5}{*}{$\begin{array}{l}\text { Closest Q fever bulk-milk-positive dairy goat } \\
\text { or dairy sheep farms }(\mathrm{km}) \S\end{array}$} & $<5 \cdot 0$ & 35 & $62 \cdot 9$ & Reference \\
\hline & $5 \cdot 0-9 \cdot 9$ & 69 & $58 \cdot 0$ & $0 \cdot 39(0 \cdot 14-1 \cdot 13)$ \\
\hline & $10 \cdot 0-14 \cdot 9$ & 53 & $41 \cdot 5$ & $0 \cdot 87(0 \cdot 30-2 \cdot 54)$ \\
\hline & $15 \cdot 0-19 \cdot 9$ & 41 & $61 \cdot 0$ & $0 \cdot 82(0 \cdot 32-2 \cdot 14)$ \\
\hline & $\geqslant 20 \cdot 0$ & 72 & $40 \cdot 3$ & $0 \cdot 42(0 \cdot 16-1 \cdot 10)$ \\
\hline \multirow[t]{2}{*}{ Year farm started $\dagger$} & Before 1990 & 165 & $44 \cdot 2$ & Reference \\
\hline & 1990 or later & 75 & $61 \cdot 3$ & $1 \cdot 97(1 \cdot 12-3 \cdot 48)$ \\
\hline \multirow[t]{2}{*}{ Distance between house and pastures } & $<30 \mathrm{~m}$ & 127 & $40 \cdot 2$ & Reference \\
\hline & $\geqslant 30 \mathrm{~m}$ & 103 & $61 \cdot 1$ & $2 \cdot 20(1 \cdot 23-3 \cdot 94)$ \\
\hline \multirow{4}{*}{ Number of male sheep $2010 \dagger$} & $<6$ & 130 & $46 \cdot 9$ & Reference \\
\hline & $6-20$ & 56 & $60 \cdot 7$ & $1 \cdot 78(0 \cdot 85-3 \cdot 75)$ \\
\hline & $>20$ & 41 & $51 \cdot 2$ & $1 \cdot 20(0 \cdot 53-2 \cdot 70)$ \\
\hline & No & 16 & $56 \cdot 3$ & $1 \cdot 30(0 \cdot 42-4 \cdot 00)$ \\
\hline \multirow[t]{2}{*}{ Zwartbles breed present on farm $\dagger$} & Yes & 30 & $63 \cdot 3$ & $1 \cdot 75(0 \cdot 89-3 \cdot 42)$ \\
\hline & No & 228 & $48 \cdot 7$ & Reference \\
\hline \multirow[t]{2}{*}{ Rijnlam breed present on farm } & Yes & 7 & $85 \cdot 7$ & $5 \cdot 72(0 \cdot 78-42 \cdot 12)$ \\
\hline & No & 251 & $49 \cdot 4$ & Reference \\
\hline \multirow[t]{2}{*}{ Blessumer breed present on farm $\dagger$} & Yes & 21 & $76 \cdot 2$ & $3 \cdot 51(1 \cdot 25-9 \cdot 81)$ \\
\hline & No & 237 & $48 \cdot 1$ & Reference \\
\hline \multirow{3}{*}{$\begin{array}{l}\text { Animals at same pasture simultaneously } \\
\text { with sheep }\end{array}$} & None & 160 & $52 \cdot 5$ & Reference \\
\hline & Cattle & 66 & $59 \cdot 1$ & $1 \cdot 30(0 \cdot 73-2 \cdot 33)$ \\
\hline & Other & 27 & $18 \cdot 5$ & $0 \cdot 21(0 \cdot 07-0 \cdot 66)$ \\
\hline \multirow{2}{*}{$\begin{array}{l}\text { Cattle at same pasture but not } \\
\text { simultaneously with sheep } \dagger\end{array}$} & Yes & 62 & $74 \cdot 2$ & $3 \cdot 90(1 \cdot 74-8 \cdot 72)$ \\
\hline & No & 188 & $42 \cdot 0$ & Reference \\
\hline \multirow[t]{3}{*}{ Straw bedding in the stables } & Yes & 243 & $50 \cdot 2$ & $0 \cdot 69(0 \cdot 40-1 \cdot 21)$ \\
\hline & No & 5 & $60 \cdot 0$ & Reference \\
\hline & No stable & 10 & $50 \cdot 0$ & $0 \cdot 31(0 \cdot 24-1 \cdot 68)$ \\
\hline \multirow{3}{*}{$\begin{array}{l}\text { How often bedding in stable } \\
\text { is refreshed } \dagger\end{array}$} & Every other day or more & 200 & $53 \cdot 0$ & $1 \cdot 77(0 \cdot 83-3 \cdot 76)$ \\
\hline & Once or twice a week & 47 & $38 \cdot 3$ & Reference \\
\hline & No stable & 10 & $50 \cdot 0$ & $1 \cdot 46(0 \cdot 49-4 \cdot 35)$ \\
\hline \multirow[t]{3}{*}{ Air enters stable through door $\dagger$} & Yes & 163 & $46 \cdot 6$ & $0 \cdot 64(0 \cdot 35-1 \cdot 18)$ \\
\hline & No & 79 & $58 \cdot 2$ & Reference \\
\hline & No stable & 10 & $50 \cdot 0$ & $0 \cdot 67(0 \cdot 25-1 \cdot 80)$ \\
\hline \multirow{2}{*}{$\begin{array}{l}\text { No farm animals present on farm } \\
\text { other than sheep }\end{array}$} & Yes & 73 & $42 \cdot 5$ & $0 \cdot 63(0 \cdot 34-1 \cdot 14)$ \\
\hline & No & 183 & $53 \cdot 6$ & Reference \\
\hline \multirow{2}{*}{$\begin{array}{l}\text { Other farm animals present in } \\
\text { sheep stables }\end{array}$} & Yes & 164 & $54 \cdot 9$ & $1 \cdot 71(0 \cdot 98-3 \cdot 00)$ \\
\hline & No & 92 & $42 \cdot 4$ & Reference \\
\hline \multirow{2}{*}{ Laying hen in stable $\dagger$} & Yes & 35 & $65 \cdot 7$ & $2 \cdot 11(0 \cdot 88-5 \cdot 04)$ \\
\hline & No & 215 & $47 \cdot 9$ & Reference \\
\hline
\end{tabular}


Table 3 (cont.)

\begin{tabular}{|c|c|c|c|c|}
\hline Variable & Category & $\begin{array}{l}\text { Frequency } \\
(N) \\
(N=261)^{*}\end{array}$ & $\begin{array}{l}\text { Sero- } \\
\text { prevalence } \\
(\%)\end{array}$ & OR $(95 \% \mathrm{CI})$ \\
\hline \multirow[t]{2}{*}{ Dairy cattle in stable $\dagger$} & Yes & 66 & $71 \cdot 2$ & $3 \cdot 37(1 \cdot 76-6 \cdot 45)$ \\
\hline & No & 184 & $42 \cdot 9$ & Reference \\
\hline \multirow{3}{*}{ Type of feed method } & By hand/ wheelbarrow & 208 & $48 \cdot 1$ & Reference \\
\hline & Mixer & 14 & $71 \cdot 4$ & $2 \cdot 91(0 \cdot 92-9 \cdot 23)$ \\
\hline & Shovel & 33 & $48 \cdot 5$ & $1.02(0.53-1.97)$ \\
\hline \multirow{2}{*}{ Lambing outside $\dagger$} & Yes & 27 & $37 \cdot 0$ & $0.55(0.26-1 \cdot 20)$ \\
\hline & No & 234 & $51 \cdot 3$ & Reference \\
\hline \multirow{2}{*}{$\begin{array}{l}\text { Number of yearlings which lambed } \\
\text { in } 2009 \dagger\end{array}$} & $<40$ & 208 & $46 \cdot 6$ & Reference \\
\hline & $\geqslant 40$ & 50 & $62 \cdot 0$ & $1.79(0.89-3.63)$ \\
\hline \multirow[t]{4}{*}{ Number dead-born lambs in 2009} & $<6$ & 49 & $40 \cdot 8$ & Reference \\
\hline & $6-14$ & 93 & $57 \cdot 0$ & $1 \cdot 88(0 \cdot 85-4 \cdot 15)$ \\
\hline & $15-24$ & 53 & $41 \cdot 5$ & $1.09(0 \cdot 47-2 \cdot 50)$ \\
\hline & $>25$ & 48 & $54 \cdot 2$ & $1.69(0.71-4.05)$ \\
\hline \multirow[t]{2}{*}{ Abortion rate 2007, 2008, 2009(\%)† } & $<4$ in all three years & 195 & $46 \cdot 2$ & Reference \\
\hline & $\geqslant 4$ in at least one year & 51 & $66 \cdot 7$ & $2 \cdot 35(1 \cdot 12-4 \cdot 92)$ \\
\hline \multirow[t]{4}{*}{ Afterbirth of normally lambed animal $\dagger$} & Leave in stable or pasture & 50 & $58 \cdot 0$ & Reference \\
\hline & & 84 & $47 \cdot 6$ & $0 \cdot 64(0 \cdot 30-1 \cdot 36)$ \\
\hline & $\begin{array}{l}\text { Direct or once a day } \\
\text { render bucket }\end{array}$ & 100 & $51 \cdot 0$ & $0 \cdot 72(0.34-1.53)$ \\
\hline & $\begin{array}{l}\text { Direct or once a day } \\
\text { manure yard } \\
\text { Other }\end{array}$ & 20 & $30 \cdot 0$ & $0 \cdot 31(0 \cdot 10-0 \cdot 97)$ \\
\hline \multirow[t]{2}{*}{ Farm tenure $\dagger$} & $\begin{array}{l}\text { Closed for ewes and rams } \\
\text { or only closed for ewes }\end{array}$ & 185 & $43 \cdot 2$ & Reference \\
\hline & $\begin{array}{l}\text { Not closed for ewes } \\
\text { and rams }\end{array}$ & 72 & $65 \cdot 3$ & $2 \cdot 37(1 \cdot 24-4 \cdot 54)$ \\
\hline \multirow[t]{2}{*}{ Sheep supplied from Groningen $\dagger$} & Yes & 26 & $69 \cdot 2$ & $2 \cdot 50(0 \cdot 82-7 \cdot 57)$ \\
\hline & No & 226 & $48 \cdot 2$ & Reference \\
\hline \multirow[t]{2}{*}{ Sheep supplied from Noord- Brabant $\dagger$} & Yes & 27 & $63 \cdot 0$ & $1.93(0.81-4.58)$ \\
\hline & No & 225 & $48 \cdot 9$ & Reference \\
\hline \multirow{2}{*}{ Sheep supplied from Noord- Holland $\dagger$} & Yes & 76 & $59 \cdot 2$ & $1.67(0 \cdot 89-3 \cdot 15)$ \\
\hline & No & 176 & $46 \cdot 6$ & Reference \\
\hline \multirow[t]{2}{*}{ Sheep supplied from Utrecht } & Yes & 15 & $73 \cdot 3$ & $2.69(0.73-9.86)$ \\
\hline & No & 237 & $49 \cdot 0$ & Reference \\
\hline \multirow{2}{*}{ Presence of hygienic locker room } & Yes & 19 & $68 \cdot 4$ & $2 \cdot 32(0 \cdot 81-6 \cdot 62)$ \\
\hline & No & 231 & $48 \cdot 5$ & Reference \\
\hline \multirow{2}{*}{ Presence of disinfection bucket $\dagger$} & Yes & 36 & $61 \cdot 1$ & $1.80(0.89-3.65)$ \\
\hline & No & 214 & $48 \cdot 1$ & Reference \\
\hline
\end{tabular}

$N$, Total number of individuals; OR, odds ratio; CI, confidence interval.

* Not all numbers add up to the total due to missing values.

$\dagger$ Variable included in later multivariate farm-based analyses before manual backward elimination.

† Urbanization degree: moderate urban area $=1000-1500$ addresses $/ \mathrm{km}^{2}$; minor urban area $=500-1000$ addresses $/ \mathrm{km}^{2}$; rural area $<500$ addresses $/ \mathrm{km}^{2}$.

$\S$ For the geographical data, information was available for all 270 individuals, including the nine people without a farmbased questionnaire.

In the environment of dairy goat farms with a history of abortion waves and of farms having PCR-positive bulk milk, relatively high levels of C. burnetii DNA were found [34]. A high goat density in the surrounding area of a participating farm is therefore considered a plausible risk factor for people living in the vicinity at the time of data collection. This was also demonstrated in several local outbreak investigations in The Netherlands in 2008-2009 [7, 8].

Maredly, several risk factors for C. burnetii seropositivity in non-dairy sheep farm residents point to cattle exposure at present or in the past. This might 
Table 4. Results of the multivariate logistic regression analysis for the individual characteristics $(P<0 \cdot 10,-2 L L)$ in relation to non-dairy sheep farm residents $\mathrm{C}$. burnetii seropositivity

\begin{tabular}{lll}
\hline \hline Variable & Category & OR $(95 \% \mathrm{CI})$ \\
\hline Age (years) & $12-19$ & $2 \cdot 81(0 \cdot 85-9 \cdot 35)$ \\
& $20-39$ & $1 \cdot 42(0 \cdot 57-3 \cdot 54)$ \\
& $40-49$ & $2 \cdot 29(1 \cdot 00-5 \cdot 24)$ \\
& $50-59$ & $1 \cdot 12(0 \cdot 50-2 \cdot 48)$ \\
Amount of work at farm & $>60$ & Reference \\
& Full working week & $2 \cdot 42(1 \cdot 13-5 \cdot 15)$ \\
& Up to half a working week & $1 \cdot 23(0 \cdot 65-2 \cdot 33)$ \\
Contact with cattle at own or other farm* & Never/occasionally & Reference \\
& Yes & $3 \cdot 87(2 \cdot 13-7 \cdot 04)$ \\
Worked in cattle sector in the past & No & Reference \\
& Yes & $1 \cdot 79(1 \cdot 01-3 \cdot 18)$ \\
\hline \hline
\end{tabular}

OR, Odds ratio; CI, confidence interval; -2LL, likelihood ratio test; AIC, Akaike's Information Criterion.

Number of observations used: 266 (AIC $=340 \cdot 38$ ).

* See animals at $<5 \mathrm{~m}$ or touch animals.

Table 5. Results of the multilevel analysis with farm-based characteristics $(P<0 \cdot 10)$ as independent factors in relation to non-dairy sheep farm residents $\mathrm{C}$. burnetii seroprevalence

\begin{tabular}{lll}
\hline \hline Variable & Category & OR $(95 \% \mathrm{CI})$ \\
\hline Goat density (number of goats $/ \mathrm{km}^{2}$ excluding own & $<2 \cdot 9$ & Reference \\
animals in a $5-\mathrm{km}$ radius) & $2 \cdot 9-11 \cdot 3$ & $1 \cdot 60(0 \cdot 75-3 \cdot 43)$ \\
& $\geqslant 11 \cdot 4$ & $3 \cdot 80(1 \cdot 67-8 \cdot 65)$ \\
Year farm started & Refore 1990 & $3 \cdot 97(1 \cdot 79-8 \cdot 82)$ \\
& 1990 or later & $5 \cdot 19(2 \cdot 36-11 \cdot 41)$ \\
Blessumer breed present on farm & Yes & Reference \\
& No & $5 \cdot 14(2 \cdot 17-12 \cdot 19)$ \\
Cattle at same pasture but not simultaneously with sheep & Yes & Reference \\
& No & $3 \cdot 24(1 \cdot 49-7 \cdot 07)$ \\
How often bedding in stable is refreshed & Every other day or more & Reference \\
& Once or twice a week & $8 \cdot 91(2 \cdot 17-36 \cdot 68)$ \\
& No stable & $0 \cdot 46(0 \cdot 23-0 \cdot 92)$ \\
Air enters stable through door & Yes & Reference \\
& No & $8 \cdot 91(2 \cdot 17-36 \cdot 68)$ \\
& No stable & $3 \cdot 33(1 \cdot 17-9 \cdot 46)$ \\
Dairy cattle present during stabling period of sheep & Yes & Reference \\
& No & $0 \cdot 34(0 \cdot 14-0 \cdot 86)$ \\
Lambing outside & Yes & Reference \\
& No & $4 \cdot 17(1 \cdot 59-10 \cdot 97)$ \\
Sheep supplied from Groningen & Yes & Reference \\
& No & $3 \cdot 93(1 \cdot 74-8 \cdot 90)$ \\
Sheep supplied from Noord-Holland & Yes & Reference \\
\hline \hline
\end{tabular}

OR, Odds ratio; CI, confidence interval; QIC, quasi-likelihood under the independence model criterion. Number of observations used: 212. Number of levels used: $107(\mathrm{QIC}=232 \cdot 9560)$.

suggest that cattle were partially responsible for the infections observed in the sheep farm residents. In a previous study in farmers (all farm types) contact with cattle was also described as a risk [27]. A recent published review including worldwide studies, suggested a higher seroprevalence of $C$. burnetii in cattle compared to goat and sheep [35]. In The Netherlands, a prevalence of $78.6 \%$ for antibodies 
Table 6. Results of the multilevel analysis with individual and farm-based characteristics $(P<0 \cdot 10)$ as independent factors in relation to non-dairy sheep farm residents $\mathrm{C}$. burnetii seroprevalence

\begin{tabular}{|c|c|c|}
\hline Variable & Category & OR $(95 \% \mathrm{CI})$ \\
\hline \multirow[t]{5}{*}{ Age (years) } & $12-19$ & $0 \cdot 96(0 \cdot 29-3 \cdot 21)$ \\
\hline & $20-39$ & $1.96(0.56-6.90)$ \\
\hline & $40-49$ & $2 \cdot 43(0.98-6 \cdot 04)$ \\
\hline & $50-59$ & $1 \cdot 54(0 \cdot 63-3 \cdot 78)$ \\
\hline & $>60$ & Reference \\
\hline \multirow[t]{2}{*}{ Contact with cattle at own or other farm* } & Yes & $2 \cdot 32(1 \cdot 02-5 \cdot 29)$ \\
\hline & No & Reference \\
\hline \multirow[t]{2}{*}{ Worked in cattle sector in the past } & Yes & $3 \cdot 98(1 \cdot 71-9 \cdot 25)$ \\
\hline & No & Reference \\
\hline \multirow{3}{*}{$\begin{array}{l}\text { Goat density (number of goats } / \mathrm{km}^{2} \text { excluding own } \\
\text { animals in a } 5-\mathrm{km} \text { radius) }\end{array}$} & $<2 \cdot 9$ & Reference \\
\hline & $2 \cdot 9-11 \cdot 3$ & $1 \cdot 11(0 \cdot 46-2 \cdot 68)$ \\
\hline & $\geqslant 11 \cdot 4$ & $5 \cdot 86(1 \cdot 81-18 \cdot 95)$ \\
\hline \multirow[t]{2}{*}{ Year farm started } & Before 1990 & Reference \\
\hline & 1990 or Later & $3 \cdot 67(1 \cdot 45-9 \cdot 31)$ \\
\hline \multirow[t]{2}{*}{ Blessumer breed present on farm } & Yes & $4.49(1 \cdot 59-12 \cdot 65)$ \\
\hline & No & Reference \\
\hline \multirow[t]{2}{*}{ Cattle at same pasture but not simultaneously with sheep } & Yes & $5 \cdot 77(2 \cdot 29-14 \cdot 56)$ \\
\hline & No & Reference \\
\hline \multirow[t]{3}{*}{ How often bedding in stable is refreshed } & Every other day or more & $4 \cdot 58(1 \cdot 69-12 \cdot 37)$ \\
\hline & Once or twice a week & Reference \\
\hline & No stable & $8 \cdot 34(1 \cdot 71-40 \cdot 60)$ \\
\hline \multirow[t]{3}{*}{ Air enters stable through door } & Yes & $0 \cdot 47(0 \cdot 21-1 \cdot 01)$ \\
\hline & No & Reference \\
\hline & No stable & $8 \cdot 34(1 \cdot 71-40 \cdot 60)$ \\
\hline \multirow[t]{2}{*}{ Dairy cattle present during stabling period of sheep } & Yes & $2 \cdot 69(0 \cdot 81-8 \cdot 95)$ \\
\hline & No & Reference \\
\hline \multirow[t]{2}{*}{ Lambing outside } & Yes & $0 \cdot 33(0 \cdot 12-0 \cdot 92)$ \\
\hline & No & Reference \\
\hline \multirow[t]{2}{*}{ Sheep supplied from Groningen } & Yes & $5 \cdot 05(1 \cdot 73-14 \cdot 69)$ \\
\hline & No & Reference \\
\hline \multirow[t]{2}{*}{ Sheep supplied from Noord-Holland } & Yes & $3 \cdot 63(1 \cdot 27-10 \cdot 33)$ \\
\hline & No & Reference \\
\hline
\end{tabular}

OR, Odds ratio; CI, confidence interval; QIC, quasi-likelihood under the independence model criterion. Number of observations used: 208. Number of levels used: $105(\mathrm{QIC}=219 \cdot 1157)$.

* See animals at $<5 \mathrm{~m}$ or touch animals.

in cattle bulk tank milk was found, confirming widespread circulation of the bacterium in cattle [36]. To further assess the risk for human infection from cattle, a similar study addressing the seroprevalence and risk factors in dairy cattle farm residents is being finalized in The Netherlands. A role for cattle in the human infections observed in the current sheep farm study, is also supported by the fact that the high seroprevalence in sheep farm residents does not seem to correspond with the low sheep seroprevalence at the participating farms $(<2 \%)$. The role of specific activities with sheep for the infection risk was presumably relatively small, although not absent taking into account the significant association between human and sheep seroprevalence at the participating non-dairy farms. Whether sheep themselves are at increased risk for infection because of contact with cattle or nearby goat populations is currently under investigation. In The Netherlands, a dominant C. burnetii genotype was identified in humans, goats, and sheep throughout the entire affected area; the genotype found in cattle appeared to be different [37, 38].

Based on the results of the present study, some recommendations can be made. First, we want to elucidate the transmission cycle between different species of ruminants and farm residents; strains from goat, sheep, cattle, and sheep farm residents could be subtyped and compared. Second, more research is needed to investigate whether the Blessumer breed is more often infected compared to other breeds. Third, 
in this study a high seroprevalence in spouses was found $(36 \cdot 3 \%$ non-dairy farm spouses, $50 \cdot 0 \%$ dairy farm spouses). Therefore, we emphasize the importance of the advice that pregnant women should avoid contact with sheep during the lambing season, and that they should avoid contact with birth products of sheep. Currently, the Dutch Health Council is preparing an advice about vaccination of high-risk professionals, including several farm populations. For this advice, they also will take into account the results of this study.

\section{Limitations}

The study of non-dairy sheep farms had a low response rate of $9 \cdot 1 \%$. As reported by several farmers not willing to participate, sheep were outside when the request to participate was made, and it would be too labour-intensive to collect about 60 sheep for blood sampling. In addition, this part of the sheep industry was not affected by the implemented control measures, mainly targeted at farms with dairy sheep and dairy goats. Therefore, non-dairy sheep farmers might be less motivated to participate compared to the small dairy sheep sector, which had a response rate of $38 \%$.

Except for differences in sheep density in the surroundings and the number of sheep on their farms, participating and non-participating non-dairy sheep farms appeared to be comparable. As both factors were not related to seropositivity, this selective response is not thought to be of influence on the study results, which are therefore considered representative for the Dutch professional non-dairy sheep sector.

At $79 \%$ of the 119 participating non-dairy farms both the farmer and partner participated in the study. Therefore, results for the farmers and partners are considered representative of the group of farmers/partners at the participating farms. It was not registered how many children aged $\geqslant 12$ years lived at the participating non-dairy farms, and we cannot be absolutely sure that the participating children were representative of all children in this age category.

\section{CONCLUSION}

This study demonstrates that $C$. burnetii infection is common in individuals living and/or working at a sheep farm in The Netherlands. Except for their sheep, the risk also seems dictated by contact with cattle at present or in the past and by nearby goat populations.

\section{ACKNOWLEDGEMENTS}

We are grateful to all participants without whom the study could not have been conducted. We thank all laboratory assistants for collection of serum samples, Jamie Meekelenkamp for laboratory analyses, Noel Peters for sending test results to participants, Sanne Kelderman for invitation mailings and providing reference data, Helen Aangenend for organizing logistics of human data collection, and Ben Bom for generating geographical information. Finally, we thank all expert members of the Q-VIVE project group and affiliated organizations for their support and advice during the study: Jan van den Bergh, Olaf Stenvers, Rob van Oosterom, Mark Paauw, Harry Stinis, Ad de Rooij, Margo Vonk, Clementine Wijkmans and Wim van der Hoek.

The study was funded by The Netherlands Organization for Health Research and Development [grant no. 50-50800-98-100: An integrated study on $\mathrm{Q}$ fever in livestock farmers and their (small) ruminants in The Netherlands]; and co-financed by the Ministry of Public Health and the Ministry of Agriculture. The funders had no role in study design, data collection and analysis, decision to publish, or preparation of the manuscript.

\section{DECLARATION OF INTEREST}

None.

\section{REFERENCES}

1. Maurin M, Raoult D. Q fever. Clinical Microbiology Reviews 1999; 12: 518-553.

2. Marrie TJ, et al. Truckin' pneumonia-an outbreak of $Q$ fever in a truck repair plant probably due to aerosols from clothing contaminated by contact with newborn kittens. Epidemiology and Infection 1989; 102: 119-127.

3. Gonder JC, et al. Cynomolgus monkey model for experimental Q fever infection. Journal of Infectious Diseases 1979; 139: 191-196.

4. Raoult D, et al. Q fever 1985-1998. Clinical and epidemiologic features of 1,383 infections. Medicine (Baltimore) 2000; 79: 109-123.

5. van der Hoek W, et al. Shifting priorities in the aftermath of a Q fever epidemic in 2007 to 2009 in The Netherlands: from acute to chronic infection. Eurosurveillance 2012; 17: pii=20059. 
6. van der Hoek W, et al. Q fever in the Netherlands: an update on the epidemiology and control measures. Eurosurveillance 2010; 15: pii $=19520$.

7. Karagiannis I, et al. Investigation of a Q fever outbreak in a rural area of The Netherlands. Epidemiology and Infection 2009; 137: 1283-1294.

8. Schimmer B, et al. The use of a geographic information system to identify a dairy goat farm as the most likely source of an urban Q-fever outbreak. BMC Infectious Diseases 2010; 10: 69.

9. Schimmer B, et al. Sustained intensive transmission of Q fever in the south of the Netherlands, 2009. Eurosurveillance 2009; 14: pii $=19210$.

10. van der Hoek W, et al. Human Q fever and non-dairy farm [in Dutch]. National Institute of Public Health and Environment, 2010. Report No.: 2010/02.

11. Koene RP, et al. A Q fever outbreak in a psychiatric care institution in The Netherlands. Epidemiology and Infection 2011; 139: 13-18.

12. Whelan $\mathbf{J}$, et al. Visits on 'lamb-viewing days' at a sheep farm open to the public was a risk factor for Q fever in 2009. Epidemiology and Infection 2012; 140: 858-864.

13. Gilsdorf A, et al. Large Q fever outbreak due to sheep farming near residential areas, Germany, 2005. Epidemiology and Infection 2008; 136: 1084-1087.

14. Hellenbrand W, Breuer T, Petersen L. Changing epidemiology of Q fever in Germany, 1947-1999. Emerging Infectious Diseases 2001; 7: 789-796.

15. Porten K, et al. A super-spreading ewe infects hundreds with $\mathrm{Q}$ fever at a farmers' market in Germany. $B M C$ Infectious Diseases 2006; 6: 147.

16. Medić A, et al. Q fever epidemic among employees in a factory in the suburb of Zadar, Croatia. Croatian Medical Journal 2005; 46: 315-319.

17. Dupuis G, et al. An important outbreak of human Q fever in a Swiss Alpine valley. International Journal of Epidemiology 1987; 16: 282-287.

18. Starnini G, et al. An outbreak of Q fever in a prison in Italy. Epidemiology and Infection 2005; 133: 377-380.

19. Manfredi Selvaggi T, et al. Investigation of a Q-fever outbreak in northern Italy. European Journal of Epidemiology 1996; 12: 403-408.

20. Wegdam-Blans MCA, et al. Evaluation of commonly used serological tests for detection of Coxiella burnetii antibodies in well-defined acute and followup sera. Clinical and Vaccine Immunology 2012; 19: 1110-1115.

21. Hussain-Yusuf $\mathbf{H}$, et al. An analysis of $Q$ fever patients 6 years after an outbreak in Newport, Wales, UK. QJM: an International Journal of Medicine 2012; 105: 10671073 .

22. Wegdam-Blans MCA, et al. Chronic Q fever: review of the literature and a proposal of new diagnostic criteria. Journal of Infection 2012; 64: 247-259.
23. Schimmer B, et al. Low seroprevalence of $Q$ fever in The Netherlands prior to a series of large outbreaks. Epidemiology and Infection 2012; 140: 27-35.

24. Hogema BM, et al. Coxiella burnetii infection among blood donors during the 2009 Q-fever outbreak in The Netherlands. Transfusion 2012; 52: 144-150.

25. Macellaro A, Akesson A, Norlander L. A survey of Q-fever in Sweden. European Journal of Epidemiology 1993; 9: 213-216.

26. Cisak E, et al. Prevalence of antibodies to Coxiella burnetii among farming population in eastern Poland. Annals of Agricultural and Environmental Medicine 2003; 10: 265-267.

27. Thomas DR, et al. The risk of acquiring Q fever on farms: a seroepidemiological study. Occupational and Environmental Medicine 1995; 52: 644-647.

28. Schimmer B, et al. Seroprevalence and Risk Factors for Coxiella burnetii (Q Fever) Seropositivity in Dairy Goat Farmers' Households in The Netherlands, 2009-2010. PLoS One 2012; 7: e42364.

29. Rauw WM, et al. Undesirable side effects of selection for high production efficiency in farm animals: a review. Livestock Production Science 1998; 56: 15-33.

30. van den Brom R, et al. Demography of Q fever seroprevalence in sheep and goats in The Netherlands in 2008. Preventive Veterinary Medicine 2012.

31. McCaughey C, et al. Human seroprevalence to Coxiella burnetii (Q fever) in Northern Ireland. Zoonoses Public Health 2008; 55: 189-194.

32. Bölske G, et al. Bovine tuberculosis in Swedish deer farms: epidemiological investigations and tracing using restriction fragment analysis. Veterinary Record 1995; 136: $414-417$.

33. Mansley LM, et al. Early dissemination of footand-mouth disease virus through sheep marketing in February 2001. Veterinary Record 2003; 153: 43-50.

34. de Bruin A, et al. Detection of Coxiella burnetii DNA on small-ruminant farms during a $\mathrm{Q}$ fever outbreak in the Netherlands. Applied and Environmental Microbiology 2012; 78: 1652-1657.

35. Guatteo R, et al. Prevalence of Coxiella burnetii infection in domestic ruminants: a critical review. Veterinary Microbiology 2011; 149: 1-16.

36. Muskens J, et al. Prevalence of Coxiella burnetii infection in Dutch dairy herds based on testing bulk tank milk and individual samples by PCR and ELISA. Veterinary Record 2011; 168: 79.

37. Roest HIJ, et al. Molecular epidemiology of Coxiella burnetii from ruminants in $\mathrm{Q}$ fever outbreak, the Netherlands. Emerging Infectious Diseases 2011; 17: 668-675.

38. Tilburg JJHC, et al. Epidemic genotype of Coxiella burnetii among goats, sheep, and humans in the Netherlands. Emerging Infectious Diseases 2012; 18: 887-889. 